\title{
É POSSÍVEL UMA LINGUAGEM CRÍTICA NA EDUCAÇÃO?
}

IS A CRITICAL LANGUAGE

POSSIBLE IN EDUCATION?

UN LANGAGE CRITIQUE EST-IL

POSSIBLE EN ÉDUCATION?

¿ES POSIBLE UN LENGUAJE

CRÍTICO EN LA EDUCACIÓN?

Raquel de Almeida Moraes*

\section{RESUMO}

O presente artigo argumenta sobre a possibilidade da existência de uma linguagem crítica na educação. Em contrapartida à educação para o senso comum, do tipo bancária e padronizadora praticada pela indústria cultural e educacional capitalista, que usa "uma linguagem simplificada para ser usada pelas massas" (Tognolli), com "invariantes fixos, clichês prontos, tradução estereotipada de tudo" (Adorno), pensamos que é possivel dialogar como "intersubjetividades não-violentas", o que envolve reconhecer a diferença, a diferença total (Gur-Ze'ev), visando despertar a consciência do "quanto os homens são enganados de modo permanente" (Adorno). Isso requer o uso de uma linguagem crítica de modo poético (Bakhtin) e dialógico-amoroso (Freire), pois, se a linguagem crítica for violenta, estará sendo utilizada a mesma lógica da dominação, não promovendo, portanto, a emancipação.

Palavras-chave: Pedagogia crítica. Linguagem. Não-violência.

* Doutora em Filosofia e História da Educação pela Universidade Estadual de Campinas (Unicamp, 1996). Professora da Faculdade de Educação da Universidade de Brasília (rachel@unb.br, http://mundoacademico.unb.br/professor/45/). 


\section{INTRODUÇÃO}

Apesar de toda ilustração e de toda informação que se difunde (e até mesmo com sua ajuda) a semiformação passou a ser a forma dominante da consciência atual, o que exige uma teoria que seja abrangente (ADORNO, 1996, p. 388).

$\mathrm{O}$ presente artigo argumenta sobre a possibilidade da existência de uma linguagem crítica na educação. Em contrapartida à educação para o senso comum, do tipo bancário e padronizadora praticada pela indústria cultural e educacional capitalista, que usa "uma linguagem simplificada para ser usada pelas massas" (TOGNOLLI, 2001), com "invariantes fixos, clichês prontos, tradução estereotipada de tudo" (ADORNO, apud PUCCI, 1995), pensamos que é possivel dialogar como "intersubjetividades não-violentas", o que envolve reconhecer a diferença, a diferença total (GUR-ZE'EV, 2001), visando despertar a consciência do "quanto os homens são enganados de modo permanente" (ADORNO, 1995). Isso requer o uso de uma linguagem crítica de modo poético (BAKHTIN, 1998) e amoroso-dialógico (FREIRE, 2001), pois, se a linguagem crítica for violenta, estará sendo utilizada a mesma lógica da dominação, não promovendo, portanto, a emancipação.

Tendo por meta desenvolver uma contra-hegemonia à linguagem autoritária e sedutora da educação bancária e padronizadora, na qual o conhecimento é considerado como mercadoria e os estudantes são sujeitos passivos, reduzindo-se a clientes nessa fase da globalização do capital, julgamos que a linguagem crítica na educação deve fazer mediações poéticas e dialógicas nos círculos de cultura, inclusive no ciberespaço, criando uma força contrária à tendência hegemônica dominante.

Para desenvolver esse argumento serão explicitadas as concepções de linguagem para Bakhtin e Freire; seu significado nas perspectivas dos Estudos Culturais e da Teoria Crítica para que se possa, enfim, estabelecer as inferências a partir da premissa geral da emancipação humana, da democracia e da não-violência, pressupostos que orientam a presente proposição.

\section{A LINGUAGEM EM MIKHAIL BAKHTIN E PAULO FREIRE}

Mikhail Bakhtin (1986) e Paulo Freire (2001) concebem a linguagem como essencialmente dialógica. Suas idéias sobre o homem e a vida são marcadas pelo princípio de que a interação entre os sujeitos é o princípio fundador tanto da linguagem como da consciência. O sentido e a significação dos signos (amplamente entendido como sons, gestos, imagens, palavras e silêncio) dependem da relação entre sujeitos e são construídos na interpretação dos enunciados. Nessa perspectiva, o centro da interlocução deixa de estar polarizado entre o eu e o tu, emissor e receptor, passando a estar inserido num movimento dialógico na comunicação em torno do significado.

Segundo Lima (2001), isso significa superar visōes de um modelo redutor, marcado pela unidirecionalidade, que coloca o emissor como propositor de mensagens fechadas e o receptor passivo diante delas. Significa transformar e redimensionar o espaço da recepção como espaço de interação e transformação e modificar os papéis de emissores e receptores, para uma dinâmica relacional co-autores/criadores. 
Em última análise, significa reconhecer que o interagir é mais do que simplesmente enviar e responder mensagens; é entender emissão e recepção como espaços recursivos, já que emissor e receptor passam a fazer parte de um processo de relaçôes interligadas por fios dialógicos. Tais relações são sempre relações em processo, isto é, estão sempre se confrontando, fazem-se e desfazem-se, constroem-se e desconstroem-se, em jogos simultâneos, dinâmicos e dialógicos.

Assumir essa ótica na educação gera desafios. No campo educacional, tradicionalmente a comunicação tem apresentado um caráter linear, impositivo e monológico. Para Bakhtin, monologia é a qualidade dos discursos autoritários em que um único sentido sobressai, impedindo que os demais venham à tona; as partes são dicotomizadas em emissor (propositor da mensagem) e receptor (receptáculo acrítico do primeiro). Na prática, percebe-se que o diálogo restringe-se a um plano inferior de detalhamento ou esclarecimento de discursos prontos, oriundos de um único emissor, e a língua passa a ser um instrumento de reprodução do sistema de dominação vigente.

$\mathrm{Na}$ perspectiva de Freire, para que o diálogo realmente aconteça é condição que os sujeitos tenham um campo de significados em comum. "Em relação dialógico-comunicativa, os sujeitos interlocutores se expressam, como já vimos, através de um mesmo sistema de signos lingüísticos" (FREIRE, 2001, p. 67).

Ademais, Freire (1987) critica o monologismo da comunicação, quando afirma que ensinar não é transferir conhecimento, mas criar as possibilidades para a sua própria produção ou construção. Para ele ensinar exige criticidade e respeito à autonomia do ser do educando. Caso contrário, serão feitos comunicados, extensão e invasão cultural, e não uma verdadeira comunicação. Para Freire (2001), o homem é um ser de relações, que, desafiado pela natureza, a transforma com seu trabalho, criando o mundo da cultura. E ao criar o mundo do trabalho e da cultura ele se percebe historicamente imerso na contradição opressores-oprimidos, advindo daí a necessidade de sua superação.

É impossível, na perspectiva freireana, compreender o pensamento fora de sua dupla função: cognoscitiva e comunicativa. Em vista disso, a educação é concebida como um ato político e de comunicação - e não de extensão -, pois a comunicação "implica uma reciprocidade que não pode ser corrompida" (FREIRE, 2001, p. 67). Comunicação é educação, é diálogo, "na medida em que não é transferência de saber, mas um encontro de sujeitos interlocutores que buscam a significação dos significados" (FREIRE, 2001, p. 69).

$\mathrm{Na}$ visão de Freire, a educação está inserida na sociedade e não descolada e reduzida a uma função capitalista de mero treinamento/ajustamento para o trabalho. O capitalismo faz uma educação do tipo "bancária", que representa "a inconciliação educador-educandos". Sob essa ótica, a educação serviria para auxiliar o processo de transformaçãa, de mudança. No livro Medo e Ousadia (1993), Freire e Shor afirmam que a mudança social seria "o estabelecimento de uma relação diferente com o conhecimento e com a sociedade” (FREIRE; SHOR, 1993, p. 48).

Assim, a mudança também se dá a partir do campo da consciência e, mais precisamente, da linguagem. No livro Pedagogia do Oprimido, Freire coloca que: "Existir, humanamente, é pronunciar o mundo, é modificá-lo. O mundo pronunciado, por sua vez, se volta problematizado aos sujeitos pronunciantes, a exigir deles um novo pronunciar" (FREIRE, 1987, p. 78). 
Dizer a palavra - que é também trabalho, é práxis, é transformação do mundo - não é privilégio de alguns, mas direito de todos. É por meio de um autêntico diálogo amoroso, crítico e reflexivo que se dá o processo de conscientização e de humanização, fim último da educação, que, para Freire, ocorre quando o homem, distanciando-se de seu mundo vivido, problematizando-o, decodificando-o criticamente, no mesmo movimento da consciência, redescobre-se como sujeito instaurador do mundo e de sua experiência.

Contudo, a conscientização não significa dissertar sobre conteúdos e doar aqueles saberes que nada têm a ver com os anseios, desejos, necessidades, esperanças e temores do povo. Para que haja uma comunicação real e não alienadora entre educador e educando é necessário que se estabeleçam, de comum acordo, aqueles conteúdos (temas geradores) que serão trabalhados; e esse processo investigativo implica uma metodologia que não pode contradizer a dialogicidade da educação libertadora.

Descobrir os temas geradores implica reconhecerem-se como homens que são, ao mesmo tempo produtos e produtores da história e, conseqüentemente, seres inacabados, e, por outro lado, reconhecer a existência daquilo que Vieira Pinto (apud FREIRE, 1987, p. 90) "chama de 'atos limites' - aqueles que se dirigem à superação e à negação do dado, em lugar de implicarem sua aceitação dócil e passiva".

Nessa perspectiva, Freire considera essencial que o educador dialógico, atuando como membro de equipe interdisciplinar, contribua para problematizar esse universo temático recolhido na investigação, ao invés de simplesmente devolvê-lo como dissertação aos homens de quem o recebeu. Em vista disso, critica o elitismo das lideranças sobre as massas oprimidas, mesmo em situações ditas revolucionárias, pois não é revolução o que na prática se configura como dominação. Para ele, uma liderança que não seja dialógica está mantendo o "dominador" dentro de si mesma, como uma sombra.

Bakhtin (1986) aprofundou os estudos sobre a relação entre infra-estrutura e superestrutura por meio da linguagem e da consciência Para ele, ao lado dos fenômenos naturais, do material tecnológico e dos bens de consumo, "existe um universo particular, o universo dos signos" (BAKHTIN, 1986, p. 32). Por sua vez, um signo "(...) não existe apenas como parte de uma realidade; ele também reflete e refrata uma outra. Ele pode distorcer essa realidade, ser-lhe fiel, ou apreendê-la de um ponto de vista específico" (BAKHTIN, 1986, p. 32).

A partir dessa premissa, resta perguntar: de onde vem o ideológico ou o signo? Para Bakhtin (BAKHTIN, 1986, p. 36): "a consciência individual não é o arquiteto dessa superestrutura ideológica, mas apenas um inquilino do edifício social dos signos ideológicos".

No entender de Bakhtin, a palavra é concebida como signo e, como tal, deve ser percebida como originária da relação social, e está presente em todos os atos de compreensão e de interpretação. Dessa maneira, como os signos mediam a relação do homem com sua realidade - como material semiótico de sua consciência -, toda atividade mental do sujeito pode ser expressa sob a forma de signos, exteriorizando-se por meio de palavras, mímica, ou outro meio, decorrente do discurso interior.

O discurso não é individual, ocorre entre interlocutores. A linguagem não é falada no vazio, mas numa situação histórica concreta, em que se interpenetram a enunciação, as condições de comunicação e as estruturas sociais, nas quais seu significado se realiza - 
nas e pelas interaçôes entre sujeitos. Essa tentativa de compreender as relaçôes entre linguagem e sociedade, num complexo diálogo entre a existência e a linguagem, entre o mundo e a mente, entre o que é dado e o que é criado, entre o mundo da experiência em ação e a representação do mundo no discurso, nos possibilita compreender a impossibilidade de uma formação individual sem alteridade, numa evidência da presença do outro na delimitação do mundo interior.

Embora para Bakhtin "todo discurso ou texto seja dialógico, nem todo texto mostra as várias vozes do discurso" (BARROS apud FARACO et al., 2001, p. 36). Nos textos polifônicos, os diálogos entre os discursos são vistos ou se deixam ver. Já nos monofônicos, essas falas ou vozes são ocultadas, dissimuladas, mascaradas; como se fossem uma única voz, um único discurso. Assim, os discursos se constituem como monofônicos ou polifônicos, ou respectivamente, autoritários e poéticos. Quanto aos discursos autoritários, nestes "abafam-se as vozes", escondem-se os diálogos e o discurso se faz discurso da verdade única, absoluta e incontestável. Já os discursos poéticos seriam aqueles em que não são encontrados vestígios de autoritarismo e coerção social, representando uma síntese que respeita as diferenças.

\section{A LINGUAGEM NA PERSPECTIVA CRÍTICA}

A partir da perspectiva dos estudos culturais de Antônio Gramsci, na sociedade capitalista a educação tem uma função política claramente definida: formar os intelectuais de diversos níveis cujas funções na sociedade civil são as de organizar a hegemonia, o "consenso espontâneo" da população (GRAMSCI, 1991; HALL, 2003). Esse "consenso" nasce do prestígio que a burguesia tem na sociedade e do aparato de coerção estatal que assegura legalmente a disciplina dos que "consentem". Mas para ele, esse "senso comum" deve ser combatido em todas as frentes, inclusive na mídia.

Para Gramsci, assim como para Freire e Gur-Ze’ev, a política após a Revolução Industrial é marcada por conflitos de classe que se expressam objetivamente por meio da exclusão/ opressão e subjetivamente por meio da ideologia, que distorce e falsifica a realidade, fazendo com que os dominados vejam como "natural" essa opressão. E a ideologia, como algo imaterial, permeia e direciona todas as esferas da sociedade, como a mídia e a educação.

Nesse sentido, a partir da concepção de ideologia desenvolvida por Marx (1986), de que a classe que é a força material dominante na sociedade é, ao mesmo tempo, sua força intelectual dominante, conforme julgamento de Darrell Moen (1998) e Stuart Hall (2003), Gramsci avançou na teoria da ideologia acrescentando à filosofia marxista o conceito de hegemonia, entendida como "falsa consciência". A hegemonia expressa o consentimento das classes subalternas à dominação burguesa, apresentando-se como a outra face do poder: a do domínio das consciências e da linguagem pela reprodução da ideologia.

Esse "consentimento espontâneo" que as pessoas têm acerca da existência de um sistema coercitivo na sociedade é transmitido/reforçado pela escola, a qual tem a tarefa de formar os intelectuais que manterão, reproduzirão e aperfeiçoarão o sistema de 
opressão sob o capitalismo. Os intelectuais que a escola produz são classificados como intelectuais orgânicos ou de mais alto nível: criadores das várias ciências, filosofia, arte, etc.; e os de nível mais baixo: administradores e divulgadores da riqueza intelectual existente.

Para Gramsci, a escola na perspectiva transformadora teria o papel de formar os intelectuais que organizarão/formarão uma nova cultura, com o objetivo de contribuir com o processo de criação de uma outra hegemonia diversa da hegemonia dominante, pois para ele é na "arena da consciência" que as elites utilizam os seus intelectuais orgânicos para manter a dominação.

Análise similar é encontrada na perspectiva da Teoria Crítica, segundo a qual, onde para Adorno e Horkheimer (1994), técnicas como o cinema e o rádio mantêm coeso o todo. Não passam de um negócio a ser utilizado como ideologia destinada a legitimar a sociedade capitalista. Assim, a técnica está inserida na lógica da racionalidade instrumental enquanto dominação da indústria cultural. Para eles, é difícil escapar dessa racionalidade instrumental, técnica, onde os meios estão acima dos fins. Assim, o cinema e o rádio deixam de veicular arte e educação tornando-se um negócio, reificando as consciências das pessoas.

As mais íntimas reaçôes das pessoas estão tão completamente reificadas para elas próprias que a idéia de algo peculiar a elas só perdura na mais extrema abstração (...). Eis aí o triunfo da publicidade na indústria cultural, a mimese compulsiva dos consumidores, pela qual se identificam às mercadorias culturais que eles, ao mesmo tempo, decifram muito bem (ADORNO; HORKHEIMER, 1994, p. 156).

Feenberg (2004) argumenta sobre a natureza essencialmente hierárquica da técnica que, ao gerar uma administração tecnocrática, cria um sistema distópico.

Críticos radicais da tecnologia, de Mumford e Marcuse até os de hoje, geralmente concordam que a emergência do poderio tecnocrático no Leste e no Oeste eclipsou a luta de classes. Também argumento que o tema central da política atual é a prevalência da administração tecnocrática e a ameaça que joga sobre a ação humana. Isso me leva a enfatizar a natureza essencialmente hierárquica da ação técnica, a relação assimétrica entre ator e objeto que, quando alcançam grandes espaços das relações humanas, tendem a criar um sistema distópico (FEENBERG, 2004, p. 4).

Para Adorno, a indústria cultural - sinônimo de mídia - gera a semicultura e, como conseqüência, há a produção de uma semiformação, onde "os conteúdos objetivos, coisificados e com caráter de mercadoria da formação cultural perduram à custa de seu conteúdo de verdade e de suas relaçóes vivas com o sujeito vivo, o qual, de certo modo, corresponde à sua definição" (ADORNO, 1996, p. 395).

E essa semiformação, em nível de linguagem, é obtida mediante:

A sequiência automatizada de operaçóes padronizadas, a disseminação de bens padronizados para a satisfação de necessidades iguais, à tendência a uniformização, os invariantes fixos, os 
clichês prontos, a tradução estereotipada de tudo, se permitem uma distribuição mais acessível e universal de bens culturais, geram, por outro lado a exclusão do novo, do diferente, do criativo" (ADORNO, apud PUCCI, 1995, p. 27).

Em nível do sujeito, Tognolli (2001) teoriza que sociedades que se relacionem "só por palavras fixas e códigos de acesso em vez da mediação e dos acontecimentos sociais, gerarão indivíduos que falarão e pensarão por clichês - ou falarão e pensarão significantes sem significados" (TOGNOLLI, 2001, p. 85).

$\mathrm{O}$ que antes era pensamento cede lugar ao não-pensamento, à automação. Para ele, chavão de linguagem, clichê, é, antes de tudo, programação. Sua hipótese é que os computadores podem absorver palavras-chave e incentivar a cultura do superficialismo.

Apoiado nos argumentos de Eugene Provenzo, Tognolli argumenta que já temos as palavras simplificadas, os newspeaks, algo próximo à linguagem da nova Oceania, do romance 1984 de George Orwell (1977), "uma linguagem simplificada para ser usada pelas massas" (TOGNOLLI, 2001, p. 177).

E esse processo de palavras-chave e clichês pode ser apenas uma parte disso: temos uma linguagem simplificada para as pessoas consumirem, o que pode tornar a cultura de massa ainda mais superficial.

\section{CONSIDERAÇÕES FINAIS}

Para Feenberg (2004) e Kellner (2004), as tecnologias da mídia e do computador estão criando profundas mudanças sociais, que exaltam ao extremo os benefícios da supervia informacional, onde se supóe que os indivíduos consigam dados e entretenimento a seu dispor, insiram-se em novas comunidades virtuais e até mesmo criem novas identidades. Contudo, eles argumentam que sua realidade enquanto integrante das mais avançadas forças de produção cria uma nova sociedade capitalista global, a qual pode reforçar as relações capitalistas de produção e hegemonia, transformando a comunicação em espetáculo. Mas, ao mesmo tempo, essas tecnologias também contêm potencial para democratizar, humanizar e transformar as desigualdades existentes no domínio de classe, raça e gênero.

Gur-Ze'ev (2000) analisa que, apesar de o ciberespaço ser uma máquina de prazer pós-moderna que visa à reprodução da dominação capitalista em sua fase globalizada e auto-controlada, ainda há a possibilidade do imprevisível e do incontrolável. Essa possibilidade faz com que os sujeitos ressuscitem o que é esquecido ou desconstruído na Rede: o Eros, a reflexão, a transcendência e a ética em um diálogo historicamente situado. Contudo, para ele, a realização do Espírito crítico não está garantida, dado que o sujeito, assim como o diálogo não é, hoje, mais do que uma utopia.

Neste sentido, consideramos pertinente o alerta de Virilio já em 1999:

Mas isso ainda não é nada comparado à inauguração, que se dará em breve, do "processamento automatizável do conhecimento", essa generalização da amnésia que constituirá a realização definitiva da indústria do esquecimento, uma vez que o conjunto das informações analógicas 
(audiovisuais e outras) deve ser substituído em breve pelo digital, com a codificação do computador tomando o lugar das linguagens das "palavras das coisas" (VIRILIO, 1999, p. 119-120).

Para Adorno (1995), em oposição à massificação e à violência da indústria cultural, desbarbarizar é a tarefa mais urgente da educação. E explicita o papel emancipador, e, portanto, ético da educação, quando alerta aos professores que comecem a despertar em seus alunos a consciência de que os homens são enganados de modo permanente. Para isso ele sugere atividades que envolvam leituras, audições e assistências conjuntas, com eles utilizando revistas, rádios, músicas e filmes comerciais (e ainda acrescentaria softwares, sites, hipertextos, etc.), mostrando-se-lhes as falsidades dos discursos ali presentes.

$\mathrm{Na}$ perspectiva dos Estudos Culturais, temos que para Gramsci a superação da hegemonia (ou falsa consciência) ocorre pela catarsis, entendida como a "passagem do momento puramente econômico (ou egoísta-passional) ao momento ético-político, isto é, a elaboração superior da estrutura em superestrutura na consciência dos homens" (GRAMSCI, 1991, p. 53).

E como se faz isso? Retomemos a Marx quando na sua terceira tese sobre Feurbach postula que: "A coincidência da modificação das circunstâncias com a atividade humana ou alteração de si próprio só pode ser apreendida e compreendida racionalmente como práxis revolucionária” (MARX, 1986, p.12).

Para Marx, a linguagem

é tão antiga quanto a consciência - a linguagem é a consciência real, prática, que existe para os outros homens e, portanto, existe para mim mesmo; e a linguagem nasce, como a consciência, da carência, da necessidade de intercâmbio com os outros homens - Onde existe uma relação, ela existe para mim. (...) A consciência, portanto, é desde o início um produto social, e continuará sendo enquanto existirem homens (MARX, 1986, p. 43).

A partir da crítica de Marx, entendemos que tanto a linguagem como a consciência são expressões da relação do homem com o mundo, tanto em nível social quanto natural. Como corolário, tem-se que: "a consciência da necessidade de estabelecer relações com os indivíduos que o circundam é o começo da consciência de que o homem vive em sociedade" (MARX, 1986, p. 44). E a partir do momento em que o homem estabelece a consciência, primitiva num primeiro momento, mas cada vez mais refinada com o passar dos tempos, ele estabelece a divisão do trabalho material e espiritual.

No entanto, Marx afirma que "não é a consciência dos homens que determina seu ser; é o seu ser social que, inversamente, determina a sua consciência” (MARX, 1971, p. 29), salientando, dessa forma, a primazia do material sobre o imaterial, dado que sua concepção do homem, e conseqüentemente da história, é o homem concreto, aquele que tem necessidades tanto materiais como imateriais e que trabalha para satisfazê-las.

Assim, o "trabalho é a objetivação da vida genérica do homem: ao não se reproduzir somente intelectualmente, como na consciência, mas ativamente, ele se duplica de modo real e percebe a sua própria imagem num mundo por ele criado" (MARX, 2001, p. 117) (grifos do autor). 
Contudo, quando o produto do trabalho é apropriado por outro homem e torna-se alienado, é roubada do homem "a sua vida genérica, a sua objetividade real como ser genérico e transforma em desvantagem a sua vantagem sobre o animal, então lhe é arrebatada a natureza, o seu corpo inorgânico" (MARX, 2001, p. 117). Assim: "A consciência que o homem tem da própria espécie altera-se por meio da alienação, de modo que a vida genérica se transforma para ele em meio" (MARX, 2001, p. 117).

A partir disso, Marx conclui que o trabalho alienado transforma a

vida genérica do homem, e também a característica enquanto sua propriedade genérica espiritual, em ser estranho, em meio da sua existência individual. Aliena do homem o próprio corpo, assim como a característica externa, a sua vida intelectual a sua vida humana (...). Uma implicação imediata da alienação do homem a respeito do produto do trabalho, da sua vida genérica, é a alienação do homem em relação ao outro homem. Quando o homem se contrapõe a si mesmo, entra do mesmo modo em oposição com outros homens (MARX, 2001, p. 117) (grifos do autor).

Para Marx, a propriedade privada decorre, portanto, "da análise do conceito de trabalho alienado, ou melhor, do homem alienado, do trabalho alienado, da vida alienada, do homem estranho a si mesmo" (MARX, 2001, p. 120).

Nesse sentido, sua concepção da essência do homem tem por pressuposto a crítica da propriedade privada, a qual

tornou-nos tão estúpidos e limitados que um objeto só é nosso quando o possuímos, ou seja, quando ele existe para nós como capital, quando o temos em posse imediata, quando o comemos, o bebemos, o usamos, nele vivemos, quando, numa palavra, o consumimos... É por isso que o lugar de todos os sentimentos físicos e morais foi ocupado pela simples alienação de todos esses sentimentos pelo sentimento de posse. A essência humana devia cair nessa miséria absoluta para fazer nascer de si própria sua riqueza interior (MARX, 2001, p. 142).

Diante disso, pensamos que a luta pela desalienação da consciência através de uma linguagem crítica requer, sobretudo, que essa linguagem crítica não seja violenta, para que seja possível libertar os sentimentos físicos e morais dominados pela posse, pois, caso isso não aconteça, se estaria utilizando a mesma lógica do opressor.

Torna-se imprescindível, portanto, em uma educação que se queira crítica, desenvolver uma práxis educativa na qual a linguagem seja a expressão das múltiplas vozes (Bakhtin), que, por meio do diálogo amoroso (Freire), busquem superar a dominação que existe nas relações de classe (Marx). Caso contrário, continuaremos a ter o que bem analisa Adorno (1996, p. 395): "No clima da semiformação, os conteúdos objetivos, coisificados e com caráter de mercadoria da formação cultural, perduram à custa de seu conteúdo de verdade e de suas relações vivas com o sujeito vivo, o qual, de certo modo, corresponde à sua definição". 


\section{Referências}

ADORNO, Theodor Ludwig Wiesengrund. Teoria da Semicultura. Trad.: Newton Ramos-deOliveira, Bruno Pucci e Cláudia B. Moura. Educação e Sociedade, Campinas, v. 17, n. 56, p. 388$411,1996$.

. Educação e emancipação. Trad.: Wolfang Leo Maar. Rio de Janeiro: Paz e Terra, 1995.

; HORKHEIMER, Max. Dialética do esclarecimento: fragmentos filosóficos. Trad.: Guido Antônio de Almeida. Rio de Janeiro: Zahar, 1994.

BAKHTIN, Mikhail. Marxismo e filosofia da linguagem. Trad.: Michel Lahud e Yara Frateschi Vieira. São Paulo: Hucitec, 1986.

FARACO, Carlos Alberto et al. (Org.). Diálogos com Bakhtin. Curitiba: UFPr, 2001.

FEENBERG, Andrew. Teoria crítica da tecnologia: nota autobiográfica. Texto original "Critical theory of technology”. Trad.: Equipe de Tradutores do Colóquio Internacional "Teoria Crítica e Educação". São Paulo: Unimep, Ufscar, Unesp. 2004.

FREIRE, Paulo. Pedagogia do oprimido. 17. ed. Rio de Janeiro: Paz e Terra, 1987.

. Pedagogia da indignação. São Paulo: Unesp, 2000.

Extensão ou comunicação? 11. ed. Rio de Janeiro: Paz e Terra, 2001.

FREIRE, Paulo; SHOR, Ira. Medo e ousadia. Trad.: Adriana Lopes. São Paulo: Brasiliense, 1986.

GRAMSCI, Antônio. Os intelectuais e a organização da cultura. 8. ed. Trad.: Carlos Nelson Coutinho. Rio de Janeiro: Civilização Brasileira, 1991.

Concepção dialética da história. Trad.: Carlos Nelson Coutinho. Rio de Janeiro: Civilização Brasileira, 1991.

GUR-ZE'EV, Ilan. E possível uma educação crítica no ciberespaço? Trad.: Newton Ramos-deOliveira. Comunicações, Piracicaba, v. 9, n. 1, p. 72-98, 2000.

A teoria crítica e a possiblidade de uma pedagogia não-repressiva. In: ZUIN, Antônio Álvares Soares et al. Ensaios Frankfurtianos, São Paulo: Cortez, 2004, p. 13-41.

Critical theory and critical pedagogy today - toward a new critical language in education. (Editor). Iyyunim Bachinuch (Studies in Education), Faculty of Education, University of Haifa, 2005. HALL, Stuart. O Problema da Ideologia. In: SOVIK, Liv (Org.). Da Diáspora: identidades e mediações culturais. Trad.: Adelaine La Guardia de Rezende et al. Belo Horizonte: EdUFMG; Brasília: Unesco, 2003, p. 265-293.

KELLNER, Douglas. Toward a civic intelligence: building a new sociotechnological infrastructure. In: FEENBERG, Andrew; BARNEY, Darin (Orgs.). Community in the digital age. New York: Rowman \& Littlefield Publishers, 2004. p. 263-285.

LIMA, Venicio A. De mídia: teoria e política. São Paulo: Perseu Abramo, 2001.

MARX, Karl. Contribuição para a crítica da economia política (Prefácio). Lisboa: Estampa, 1971 (Col. Teoria).

. Manuscritos econômico-filosóficos. Trad.: Alex Marins. São Paulo: Martin Claret, 2001.

MARX, Karl; ENGELS, Frederich. Ideologia alemã: Feurbach. 2. ed. Trad.: José Carlos Bruni, Marco Aurélio Nogueira. São Paulo: Hucitec, 1986.

MOEN, Darrell Gene. Analysis of social transformative movements in advanced capitalism: a neo-gramscian approach. Journal of Policy and Culture: v. 3. March 1998. Disponível em: <www.dgmoen.net/essays/essay_4.html>. Acesso em: 11 mar. 2007. 
MORAES, Denis (Org.). Sociedade midiatizada. Trad.: Carlos Frederico Moura da Silva, Maria Coimbra Guedes, Lúcia Pimentel. Rio de Janeiro: Mauad, 2006.

ORWELL, George. 1984. São Paulo: Companhia Editora Nacional, 1977.

PUCCI, Bruno. Teoria crítica e educação. Petrópolis: Vozes, 1995.

TOGNOLLI, Cláudio Júlio. A sociedade dos chavões: presença e lugar-comum na comunicação. São Paulo: Escrituras, 2001.

VIRILIO, Paul. A bomba informática. Trad.: Luciano Vieira Machado. São Paulo: Estação Liberdade, 1999. 


\section{R. A. Moraes}

\section{Is a critical language possible in education?}

\section{Abstract}

The present paper argues the possible existence of a critical language in education. As a counterpart to education for common sense, typical of banking and standardized education practiced by the cultural and educational capitalistic industry, which uses "a simplified language for the use of the masses" (Tognolli), with "fixed invariables, ready made clichés, and a stereotypical translation of everything" (Adorno), the argument of this paper is to show that it is possible to dialogue with "non-violent intersubjectivities" - which involves recognizing the difference, the total difference (Gur-Ze'ev), aiming to awaken the consciousness of how "men are deceived in a permanent way" (Adorno). This requires the use of critical language in poetic (Bakhtin) and dialogical-loving (Freire) way for, if the critical language is authoritarian and violent, it will be used within the same logic of domination, consequently hindering emancipation.

Keywords: Critical pedagogy. Language. Non-violence.

\section{Un langage critique est-il possible en éducation?}

\section{Résumé}

Le présent article argumente la possible existence du langage critique dans l'éducation. Comme contrepartie de l'éducation pour le sens commun, typique de l'éducation bancaire et standardisée que pratique l'industrie culturelle et éducationnelle capitaliste, qui utilise "un langage simplifié pour l'utilisation des masses" (Tognolli), avec des "invariables fixes, des clichés tout prêts et une traduction stéréotypée de tout" (Adorno), l'argument de ce texte est de montrer qu'il est possible de dialoguer avec les "intersubjectivités non-violentes" - ce qui implique reconnaître la différence, la différence totale (Gur-Ze'ev) dans le but d'éveiller la conscience de comment "les hommes sont déçus en permanence" (Adorno). Ceci requiert l'utilisation d'un langage critique de manière poétique (Bakhtin) et dialogiqueamoureuse (Freire) car si le langage est autoritaire et violent, il sera utilisé dans la même logique de la domination et, conséquemment, sans promouvoir l'émancipation.

Mots clefs: Pédagogie critique. Langage. Non-violence.

\section{¿Es posible un lenguaje crítico en la educación?}

Resumen

El presente artículo discute la posibilidad de existir un lenguaje crítico en la educación. Como contrapartida a la educación para el sentido común, del tipo bancaria y padronizadora practicada por la industria cultural y educacional capitalista, que usa "un lenguaje simplificado para ser usado por las masas" (Tognolli), con "invariantes fijos, clichés listos, traducción estereotipada de todo" (Adorno), pensamos que es posible dialogar como "intersubjetividades no violentas", lo que envuelve reconocer la diferencia, la diferencia total (Gur-Zéev), visando despertar la conciencia del "cuánto los hombres son engañados de modo permanente" (Adorno). Eso exije el uso de un lenguaje crítico de modo poético (Bakhtin) y dialógico-amoroso (Freire), pues caso el lenguaje crítico sea violento, estará siendo utilizada la misma lógica de la dominación, no promoviendo, por lo tanto, la emancipación.

Palabras-clave: Pedagogía crítica. Lenguaje. No violencia.

Recebida I ${ }^{\text {a }}$ versão em: 29.09.2006

Aceita $2^{\text {a }}$ versão em: 30.03.2007 